\title{
PEMAHAMAN KELUARGA TENTANG TINDAKAN ECT NON PREMEDIKASI DI RSJD DR. AMINO GONDOHUTOMO PROVINSI JAWA TENGAH
}

\author{
Fery Agusman MM ${ }^{1}$, Dwi Indah Iswanti ${ }^{2}$, Sri Puji Lestari ${ }^{3}$ \\ 1, 2, 3 STIKES KARYA HUSADA \\ E-mail:ferysinga@gmail.com
}

\begin{abstract}
Abstrak
Kesehatan jiwa masih menjadi salah satu permasalahan kesehatan yang signifikan di dunia, termasuk di Indonesia. Salah satu bentuk terapi penanganan kesehatan jiwa adalah Electro Convulsive Therapy. Terapi ECT merupakan suatu jenis pengobatan somatik dimana arus listrik digunakan pada otak melalui elektroda yang ditempatkan pada pelipis. Studi ini eksplorasi pemahaman keluarga tentang tindakan ECT non premedikasi di RSJD Dr. Amino Gondohutomo Provinsi Jawa Tengah.

Tujuan penelitian ini adalah mengeksplorasi pemahaman keluarga tentang tindakan ECT non premedikasi di RSJD Dr. Amino Gondohutomo Provinsi Jawa Tengah.

Desain penelitian yang digunakan adalah desain penelitian deskriptif kualitatif. Partispisan dalam penelitian ini adalah 3 orang keluarga pasien yang mendapatkan terapi ECT non premedikasi $\geq 2$ kali.

Hasil penelitian menunjukkan responden mampu menjelaskan definisi ECT non premedikasi sebagai menggunakan aliran listrik untuk menimbulkan kejang, indikasi pada pasien dengan resistensi obat dan gejala psikotik, manfaat ECT premedikasi mempercepat kesembuhan, dampak ECT non premedikasi adalah terjadi mual muntah, amnesia sementara, dan gigi goyang.

Diharapkan petugas kesehatan dapat membantu keluarga pasien yang anggota keluarganya dilakukan ECT Non Premedikasi untuk memberikan edukasi tentang pengertian, indikasi, manfaat dan prosedur ECT Non Premedikasi.
\end{abstract}

Kata kunci : Pemahaman keluarga, ECT Non Premedikasi

\section{Family's Understanding Of The Non-Premedicated ECT Treatment In The RSJD. Amino Gondohutomo Central Java Province.}

\begin{abstract}
Mental health is one of the most significant health problems in the world, including in Indonesia. The one of mental health treatment therapy is Electro Convulsive Therapy. ECT therapy is a type of somatic treatment in which electrical current is used in the brain through electrodes placed at the temples. This study explores the family's understanding of the non-premedicated ECT treatment in the RSJD. Amino Gondohutomo Central Java Province.

The research design that be used was descriptive qualitative research design. Participants in this study were 3 family of patients that receiving non-premedicated ECT therapy $\geq 2$ times in the RSJD. Amino Gondohutomo Central Java Province.

The results of the study showed that respondents were able to explain the definition of non premedication ECT as using the flow of electricity to cause seizures, indications in patients with drug resistance and psychotic symptoms, the benefits of premedication ECT accelerate recovery, non-premedication ECT effects were nausea vomiting, temporary amnesia.
\end{abstract}


The health workers should be can help families of patients whose family members have ECT Non Premedication to educate about the understanding, indication, benefits and procedures of ECT Non Premedication.

Keywords : family's understanding, non-premedicated ECT

\section{Pendahuluan}

Kesehatan jiwa masih menjadi salah satu permasalahan kesehatan yang signifikan di dunia, termasuk di Indonesia. Menurut data WHO (2016), terdapat sekitar 35 juta orang terkena depresi, 60 juta orang terkena bipolar, 21 juta terkena skizofrenia, serta 47,5 juta terkena dimensia. Di Indonesia, dengan berbagai faktor biologis, psikologis dan sosial dengan keanekaragaman penduduk; maka jumlah kasus gangguan jiwa terus bertambah yang berdampak pada penambahan beban negara dan penurunan produktivitas manusia untuk jangka panjang (Patricia, 2014).

Terapi elektrokonvulsif (ECT) merupakan suatu jenis pengobatan somatik dimana arus listrik digunakan pada otak melalui elektroda yang ditempatkan pada pelipis. Arus tersebut cukup menimbulkan kejang grand mal, yang darinya diharapkan efek yang terapeutik tercapai. Mekanisme kerja ECT sebenarnya tidak diketahui, tetapi diperkirakan bahwa ECT menghasilkan perubahan-perubahan biokimia di dalam otak (Peningkatan kadar norepinefrin dan serotinin) mirip dengan obat anti depresan (Budi P, 2005).

Studi pendahuluan yang dilakukan pada tanggal bulan Pebruari 2017 melalui wawancara dengan kepala ruang ECT RSJD Dr. Amino Gondohutomo Provinsi Jawa Tengah menyatakan bahwa ruang ECT setiap hari melakukan tindakan ECT Non Premedikasi 15 pasien / hari dan ECT Premedikasi 5 pasien / hari. Dari wawancara yang dilakukan kepada 3 kelurarga pasien yang menjalani ECT, diapatkan data mengenai dimensi fisik, dimensi psikologi, dimensi lingkungan dan dimensi sosial. Data yang diperoleh dari dimensi fisik ; keluarga pasien mengungkapkan saat menengok pasien di ruang rawat inap pasien tampak kesakitan dipunggung setelah dilakukan ECT dan merasakan pusing yang terkadang mengganggu aktifitasnya. Ketiga keluarga pasien mengungkapkan tidak bisa cepat pulang karena jadwal ECT seminggu tiga kali dan dilakukan sebanyak enam kali. Ketiga keluarga pasien mengungkapkan bahwa pasien mengalami nafsu makan kurang dikarenakan setelah ECT mengalami mual dan muntah. 
Data yang diperoleh dari dimensi psikologi, 2 keluarga pasien mengatakan bahwa pada awal diberitahu akan dilakukan ECT, mereka selalu berfikir negatif tentang kesembuhannya. Satu keluarga pasien mengatakan bahwa dirinya sudah menerima kondisi anaknya semenjak awal harus di ECT. Ketiga keluarga pasien saat ini menerima kondisi yang harus anaknya di ECT karena memang sudah jalan yang ditentukan Tuhan. Data yang diperoleh dari dimensi hubungan sosial, ketiga keluarga pasien mengatakan bahwa pasien masih dapat berhubungan dengan orang lain secara baik. Satu keluarga pasien mengatakan anaknya masih dapat membantu pekerjaan rumah..Data yang diperoleh dari dimensi lingkungan, ketiga pasien mengatakan bahwa pembiayaan ECT ditanggung oleh pemerintah karena keluarga pasien ikut BPJS,. Hanya untuk transportasi saat menengok menggunakan uang sendiri.

Dari fenomena tersebut peneliti tertarik untuk melakukan penelitian "Studi eksplorasi pemahaman keluarga tentang tindakan ECT non premedikasi di RSJD Dr. Amino Gondohutomo Provinsi Jawa Tengah”.

\section{Tinjauan Teoritis}

Keluarga adalah unit terkecil dari masyarakat yang terdiri dari atas kepala keluarga dan beberapa orang yang berkumpul dan tinggal disuatu tempat dibawah suatu atap dalam keadaan saling ketergantungan (Puspitawati.H, 2013) Menurut Ki Hajar Dewantara, Keluarga adalah sekumpulan beberapa orang yang karena terikat satu turunan lalu mengerti dan merasa berdiri sebagai satu gabungan yang hakiki, esensial, enak dan berkehendak bersama - sama memperteguh gabungan untuk memuliakan masing - masing anggotanya.

pemahaman adalah suatu situasi yang dialami individu dimana seseorang mengenal tentang potensi baik fisik maupun psikis sehingga individu memahami arah dan tujuan hidupnya. Potensi fisik adalah sejumlah kemampuan yang ada pada anggota badan dan panca indra individu sedangkan potensi psikis mencakup $m$ inat, nilai dan sikap. Yang dimaksud pemahaman disni tidak hanya terbatas pengenalan individu pada keunggulannyatetapi mencakup kekurangan yang dalam diri (Notoadmojo, 2012).

ECT ( Electro Confulsive Therapy ) non premedikasi merupakan bentuk pengobatan shok yang menjadi pengobatan modern dan merupakan pengobatan yang diperlukan dalam kasus pasien dengan resistensi terhadap obat Psikofarmaka. ${ }^{7}$ Tindakan tersebut menggunakan aliran listrik dan menimbulkkann kejang pada penderita baik tonik maupun klonik tanpa 
menggunakan obat anestesi sebelumnya. ECT diidentifikasikan sebagai treatmen khusus untuk pengobatan depresi, skizofrenia, resiko bunuh diri, dan penyakit depresi lainya (Suharsono.E, 2016)

\section{Metode Penelitian}

Pelaksanaan penelitian ini telah dilaksanakan di Ruang ECT RSJD Dr. Amino Gondohutomo Semarang dari bulan April 2017 sampai dengan bulan Januari 2018. Jenis penelitian yang digunakan adalah penelitian kualitatif dengan pendekatan fenomenologikal. Penelitian kualitatif dipilih karena peneliti ingin mengetahui pemahaman keluarga tentang ECT non premedikasi.

Partisipan dalam penelitian ini adalah Keluarga Pasien yang anggota keluarganya yang dilakukan ECT non premeikasi dan telah dilakukan ECT non premedikasi $\geq 2$ kali. Jumlah partisipan sebanyak 3 orang ditentukan dengan teknik purposive sampling.

Data dikumpulkan dengan cara wawancara mendalam (in depth interview), yaitu peneliti mengumpulkan data secara mendalam dengan cara langsung tatap muka dengan keluarga pasien. Wawancara mendalam dilakukan untuk mengetahui pemahaman keluarga pasien yang anggota keluarganya dilakukan ECT non premedikasi. Dalam pelaksanaan penelitian ini untuk pengumpulan data dimulai dengan melakukan wawancara secara mendalam.

\section{Hasil Penelitian}

1) Karakteristik Responden

Tabel 4.1 Distribusi Karakteristik Responden

\begin{tabular}{cllcl}
\hline No & Kode & Usia & Pendidikan & Status \\
$\mathrm{e}_{1}$ & P 1 & 50 tahun & SMP & Bekerja \\
$\mathrm{r}_{2}$ & P 2 & 45 tahun & SMA & Bekerja \\
$\mathrm{d}_{3}$. & P 3 & 47 tahun & SMP & Bekerja \\
$\mathrm{a}$
\end{tabular}

Berdasarkan Tabel 4.1 menunjukkan bahwa partisipan penelitian berumur berkisar antara 30 - 50 tahun. Dimana kelompok umur tersebut tergolong usia dewasa dengan fase tugas perkembangan keluarga merawat anak. Keluarga berupaya memberikan perhatian, merawat anak dengan sebaik-baiknya dan 
memberikan perawatan dan memperhatikan pendidikan bagi buah hatinya. Ketika anak sakit keluarga berupaya memberikan perawatan yang terbaik dengan membawa ke pusat pelayanan kesehatan seperti Rumah Sakit.

Pendidikan partisipan seluruhnya adalah masuk dalam kategori pendidikan menengah. Berdasarkan tingkat pendidikan partisipan sangat dimungkinkan bahwa pengetahuannya tentang kesehatan jiwa cukup baik.

2) Karakteris Pemahaman keluarga tentang tindakan ECT non premedikasi

Berdasarkan hasil wawancara : Pemahaman keluarga tentang tindakan ECT non premedikasi selengkapnya disajikan sebagai berikut:

\section{Bagan 4.1}

Kotak 1

"Terapi selain pakai obat pil, karena pakai obat pil itu perkembangannya katanya lama. La itu pakai listrik terus nanti muncul kejang. Itu katanya namanya terapi kejang. yang katanya ndk pakai obat bius yang lebih murah. Persiapannya disuruh puasa 4 jam sebelum ECT " (P1)

"Setau saya terapi pakai listrik, disetrum ben kejang.Tapi nggak pakai obat bius, nggak diinfus dulu. Jadi selain minum obat pil itu, ditambah terapi listrik. disuruh puasa dari malamnya". (P2)

"ECT itu seperti disetrum pakai listrik. dijelaske dokter itu bukan disetrum, tapi terapi listrik yang bisa bikin kejang. itu yang nggak pakai obat bius.”(P3)

Hasil jawaban partisipan di atas menunjukkan bahwa pemahaman keluarga tentang tindakan ECT non premedikasi merupakan terapi non farmakologi dengan menggunakan aliran listrik tanpa obat bius dengan persiapan puasa 4 jam sebelum tindakan dan dilakukan di ruang ECT.

\section{3) Indikasi ECT Non premedikasi}

\section{Bagan 4. 2}

Kotak 2
"dah sering keluar masuk RSJ sini, kebal sama obat pil pa gimana. susah makan, diam
seperti patung, depresi." (P1)
"pengen bunuh diri, diam nggak mau ngomong, Wis to kaya orang depresi banyak
pikiran. karna minum obat tok kayak udah nggak konjat.” (P2)
"udah lima hari di sini,belum ada perkembangan, nggak mau maem,minum obat juga
dipaksa, ngamuk." (P3)

\section{Jurnal SMART Keperawatan Sekolah Tinggi Ilmu Kesehatan (STIKes) Karya Husada}

Semarang www.stikesyahoedsmg.ac.id/ojs/index.php/sjkp(perawat) 
Hasil wawancara tersebut di atas menunjukkan partisipan memahami tentang indikasi ECT non premedikasi adalah pasien dengan berdiam diri, depresi, tidak mau makan, percobaan bunuh diri, resisten obat antidepresan, dan mengamuk.

\section{4) Manfaat ECT non Premedikasi}

\section{Bagan 4. 3}

Kotak 3

"Adik saya biar mau makan banyak lagi, nggak depresi lagi Sudah mau ngomong. Pastinya lebih cepat pulang dibandingkan hanya dengan minum obat saja mbak, karna perkembangannya lebih cepet. mengurangi depresi, cepet sembuh, gampang minum obat, mau makan." (P1)

"Supaya lupa tentang pikiran mau bunuh diri,tidak depresi lagi, jadi mau ngomong lagi, cepat pulang." (P2)

"Pastinya supaya anak cepet sembuh, ada perkembangan sedikit-sedikit, nggak ngamukan lagi.”(P3)

Hasil wawancara tersebut di atas menunjukkan partisipan manfaat ECT Non Premedikasi mengurangi depresi, mengatasi kecenderungan bunuh diri, menurunkan perilaku amuk, dan hari rawat lebih pendek.

\section{5) Dampak ECT Non Premedikasi}

\section{Bagan 4. 4}

Kotak 4

"kalo habis di Ect tu kok sering mual, kata perawat ndk boleh dikasih maem dulu takutnya muntah. brarti mungkin dengan kejang itu bisa jadi giginya patah.” (P1)

"kalo habis di ECT anak saya seperti lupa, pandangan kosong" (P2)

"anak saya setelah ECT yang pertama kemarin itu malah seperti linglung, nggak tau sekarang dimana dan nggak ingat kapan dibawa kesini tapi nggak lama". (P3)

Hasil wawancara tersebut di atas menunjukkan partisipan memahami tentang dampak ECT Non Premedikasi diantaranya mual, muntah, gigi patah, kadang pelupa kalau dilakukan ECT dan tidak ingat kejadian sebelum ECT non premedikasi.

\section{Pembahasan}

\section{Jurnal SMART Keperawatan Sekolah Tinggi Ilmu Kesehatan (STIKes) Karya Husada}

Semarang www.stikesyahoedsmg.ac.id/ojs/index.php/sjkp(perawat) 


\section{Pemahaman keluarga tentang tindakan ECT Non Premedikasi}

Hasil wawancara menemukan bahwa pemahaman keluarga tentang tindakan ECT Non Premedikasi di RDSJ DR Amino Gondohutomo Provinsi Jawa Tengah merupakan terapi non farmakologi dengan menggunakan aliran listrik untuk menimbulkan kejang, atau disebut terapi kejang listrik yang tidak menggunakan obat anestesi sebelumnya, puasa 4 jam sebelum tindakan, dan dilakukan di ruang ECT.

Hal ini sesuai dengan yang diungkapkan oleh triangulasi sumber dan triangulasi teori bahwa pemahaman keluarga tentang tindakan ECT Non Premedikasi adalah Tindakan tersebut menggunakan aliran listrik dan menimbulkkann kejang pada penderita baik tonik maupun klonik.

Di RSJD Dr. Amino Gondohutomo Provinsi Jawa Tengah pasien yang dilakukan tindakan ECT Non Premedikasi dengan persiapan puasa 4 - 6 jam kemudian saat di ruang ECT pasien akan terpasang elektroda di pelipis dan dipasang OPA (oroparyng) untuk mencegah gigi patah dan bibir tergigit, setelah itu pasien akan dilakukan kejutan berupa aliran listrik dengan menggunakan alat yang sudah sesuai standar. Pasien akan mengalami kejang tonik dan klonik kurang lebih 10 - 20 detik.

\section{Indikasi ECT Non Premedikasi}

Hasil wawancara dengan partisipan tentang indikasi ECT Non Premedikasi antara lain pasien yang sudah resisten dengan obat antidepresan, depresi kronis, kataton yang ditandai dengan sulit makan sulit minum obat dan berdiam diri, pasien kecenderungan bunuh diri, serta pasien agresif atau amuk.

Hal ini sesuai dengan yang diungkapkan oleh triangulasi sumber dan triangulasi teori bahwa indikasi ECT Non Premedikasi adalah Gangguan efek yang berat seperti pasien dengan gangguan bipolar atau depresi; Pasien dengan bunuh diri akut yang cukup lama tidak menerima pengobatan dan pada pasien bunuh diri yang aktif dan tidak mungkin menunggu antidepresan bekerja; dan Gangguan skizofrenia kakatonik tipe stupor atau tipe excited memberikan respon yang baik dengan ECT (Ann Isaacs, 2005).

\section{Manfaat ECT Non Premedikasi}


Hasil penelitian tentang manfaat ECT non premedikasi adalah menurunkan depresi, mengatasi kecenderungan bunuh diri, menurunkan perilaku amuk, serta hari rawat menjadi lebih pendek dibanding terapi farmakologi saja, sehingga biaya perawatan lebih murah.

Hal ini sesuai dengan yang diungkapkan oleh triangulasi sumber dan triangulasi teori bahwa manfaat ECT non premedikasi sesuai dengan pendapat individual yang mendukung tentang ECT Non Premedikasi dari jurnal Yongky tahun 2012 menurut "Reus V.L. bahwa ECT non premedikasi lebih efektif dari pada penggunaan obat-obat antidepresan pada penderita depresi berat, apalagi penderita tersebut resisten terhadap penggunaan obat antidepresan tersebut dan penggunaan obat antidepresan pada penderita yang melakukan percobaan bunuh diri (PBD) memerlukan suatu perawatan yang khusus". "Curtis Hartmann pengacara di Massachusetts barat, mengatakan bahwa, ECT adalah pengobatan yang terakhir untuk depresi berat yang dideritanya. Dia bangun 20 menit dan dirasakan pusing dan depresi beratnya hilang. Terima kasih kepada ECT yang dikatakan menakutkan tetapi memberikan sesuatu harapan".

\section{Dampak ECT Non Premedikasi}

Hasil penelitian tentang dampak ECT Non Premedikasi adalah terjadi mual muntah, amnesia sementara, dan gigi goyang.

Hal ini sesuai dengan yang diungkapkan oleh triangulasi sumber dan triangulasi teori bahwa dampak ECT Non Premedikasi sesuai dengan artikel yang ditulis oleh Ikky Nabila yang ditulis dalam jurnal kesehatan Andalas 2015, terjadi penurunan daya ingat sesudah ECT sebanyak $60 \%$ yaitu pada jenis immediete dan recent memory. Sesudah ECT dapat terjadi penurunan daya ingat sebanyak $75 \%$ terutama pada kejadioan yang baru saja terjadi, sedangkan ingatan jangka panjang tetap utuh.

Menurut laporan dari American Psychiatry Association, tidak pernah dilaporkan kejadian kerusakan otak setelah dilakukan ECT. Namun mendapatkan adanya akibat yang langsung terjadi pada pasien ECT yaitu: (1) Amnesia antegrade dan (2) Amnesia yang retrograde. Hal ini tidak berlangsung lama, selanjutnya beberapa minggu sampai beberapa bulan, ingatan akan kembali. Walaupun tidak didapatkan akibat yang signifikan namun pemberian ECT dapat menimbulkan perubahan neurochemical. 


\section{Kesimpulan}

Pemahaman keluarga tentang tindakan ECT non premedikasi merupakan terapi non farmakologi dengan menggunakan aliran listrik untuk menimbulkan kejang, atau disebut terapi kejang listrik yang tidak menggunakan obat anestesi sebelumnya, puasa 4 jam sebelum tindakan, dan dilakukan di ruang ECT.

Indikasi ECT non premedikasi adalah pasien dengan resisten dengan obat antidepresan, depresi kronis, kataton yang ditandai dengan sulit makan sulit minum obat dan berdiam diri, pasien kecenderungan bunuh diri, serta pasien agresif atau amuk. Manfaat ECT Non Premedikasi menurunkan depresi, mengatasi kecenderungan bunuh diri, menurunkan perilaku amuk, serta hari rawat menjadi lebih pendek dibanding terapi farmakologi saja, sehingga biaya perawatan lebih murah. Dampak ECT Non Premedikasi terjadi mual muntah, amnesia sementara, gigi goyang

\section{Saran}

Diharapkan petugas kesehatan dapat membantu keluarga pasien yang anggota keluarganya dilakukan ECT Non Premedikasi untuk memberikan edukasi tentang pengertian, indikasi, manfaat dan prosedur ECT Non Premedikasi.

Keterlibatan keluarga dalam merawat pasien dengan indikasi ECT Non Premedikasi misalnya mendampingi pasien selama pre dan post ECT Non Premedikasi agar lebih paham tentang manfaat dan dampak dari ECT Non Premedikasi.

\section{Daftar Pustaka}

Ann Isaacs; alih bahasa Dean Praty. (2005). Keperawatan Kesehatan Jiwa dan Psikiatri. EGC. Jakarta

Budi P. (2005). Pedoman Perawatan Pasien. 88-90. Jakarta. EGC

Nabila Nandinanti,Ikky. (2015). Efek Elektro Convulsive Therapy terhadap Daya Ingat Pasien Skizofrenia diRSJ Prof.HB. Sa'anin Padang. Jurnal Kesehatan Andalas. Padang Notoatmodjo. (2012). Metodologi Penelitian Kesehatan. Rineka Cipta. Jakarta 
Patricia. (2014). Keperawatan Kesehatan Jiwa Psikiatri. 44-47. Jakarta. EGC

Puspitawati.H. (2013). Konsep dan Teori Keluarga. PT IPB Press. Bogor

Suharsono.E. (2016). Teori Peran Konsep, Devariasi dan Implikasinya. Gramedia Digital. Jakarta

Yongky.(2012). Pro dan Kontra Terhadap Terapi Kejang Listrik Sebagai Terapi Alternatif Medis Pada Pasien Psikotik. Jurnal Kedokteran Widya Tahun 28 Nomor 317. Bogor 